University of Nebraska - Lincoln

DigitalCommons@University of Nebraska - Lincoln

Textile Society of America Symposium

Proceedings

Textile Society of America

2020

\title{
The Maker's Mark?: An Examination of an Embroidered Rebozo and its Potential Signature
}

Eleanor A. Laughlin

Follow this and additional works at: https://digitalcommons.unl.edu/tsaconf

Digitart of the Art and Materials Conservation Commons, Art Practice Commons, Fashion Design

Commens, Fiber, Textile, and Weaving Arts Commons, Fine Arts Commons, and the Museum Studies detwerkns

Logo

This Article is brought to you for free and open access by the Textile Society of America at

DigitalCommons@University of Nebraska - Lincoln. It has been accepted for inclusion in Textile Society of America

Symposium Proceedings by an authorized administrator of DigitalCommons@University of Nebraska - Lincoln. 


\title{
The Maker's Mark?: An Examination of an Embroidered Rebozo and its Potential Signature
}

\author{
Eleanor Laughlin
}

elaughlin@arts.ufl.edu

Mexican rebozos (shawls) range in fiber, design, and function from those worn by indigenous women made of maguey or cotton and used to carry children or heavy loads, to those made of silk that feature fancy dyes or embroidery, which served as elegant accessories. ${ }^{1}$ Among the historic embroidered examples is a luxurious subtype called the "landscape" rebozo, which featured scenes of quintessentially Mexican locations or events embroidered into the fabric of the shawl for women of the Spanish aristocracy in Mexico. Most rebozos, in the past as in the present, were made by anonymous weavers.

In previous papers, I have argued that this landscape rebozo from the Philadelphia Museum of Art's collection depicts a dia de campo (day in the country) and is in a visual dialog with French and Indian printed fabric, due to the transatlantic colonial fashion for luxurious retreats in the countryside (Figure 1). ${ }^{2}$ While still honoring those points, today I turn to a subtler aspect of the story presented in the vignettes gently embroidered on the surface of this rebozo: the shawl's own story, and perhaps that of the maker.

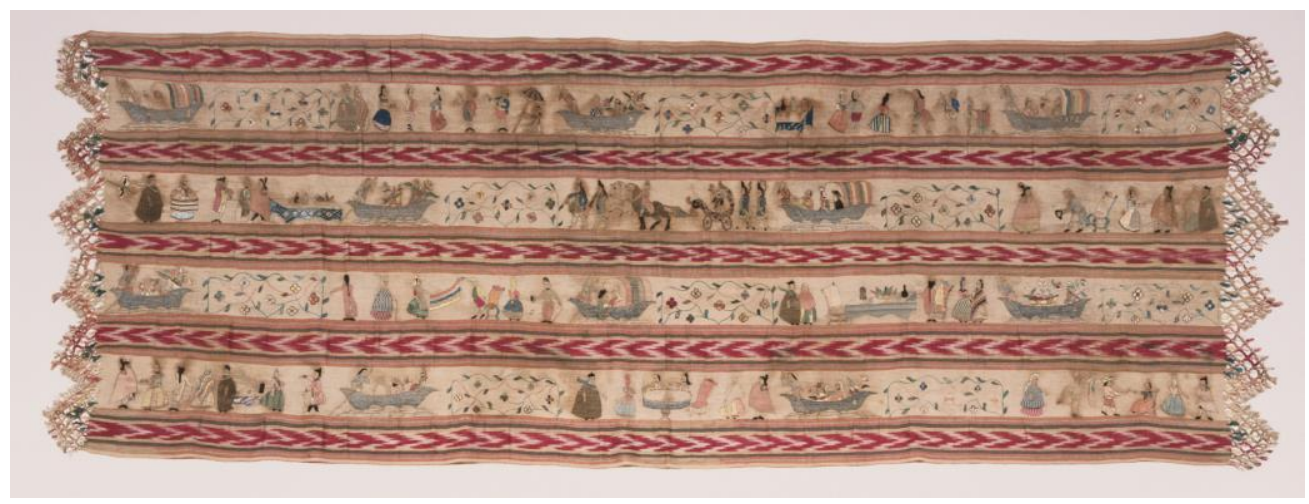

Figure 1. Mexican Rebozo, late $18^{\text {th }}$ century, silk, embroidered with cotton, silk, and metallic thread, Philadelphia Museum of Art, Gift of Mes. George W. Childs Drexel, 1939, 1939-1-19.

\footnotetext{
${ }^{1}$ For general information about rebozos, see Castelló Iturbide, El rebozo (Mexico: Electrocom, 1979); Castelló Iturbide and de Orellana, "El rebozo," in Artes de México 90 (2008); Sayer, Costumes of Mexico (Austin: University of Texas Press, 1985), as well as Textiles from Mexico (Seattle: University of Washington Press, 2002), and Mexico: Clothing and Culture (Ontario: Royal Ontario Museum of Art, 2015); Velásquez, El rebozo en el estado de México (México: Instituto Mexiquence de cultura, 2002). For additional information about the Philadelphia landscape rebozo, see Elena Phipps, "Shawl (Rebozo)," in Interwoven Globe: The Worldwide Textile Trade 1500-1800, edited by Amelia Peck (New York: Metropolitan Museum of Art, 2013).

${ }^{2}$ Eleanor A. Laughlin, "The Intercontinental Reflections of an Eighteenth-Century Mexican Rebozo" (2016). Textile Society of America Symposium Proceedings. 1022, http://digitalcommons.unl.edu/tsaconf/1022; as well as a paper presented for the Southeastern Society of Eighteenth-Century Studies (SEASECS) Conference, Savannah, Georgia, "Woven with Threads of Gold: The Rebozo and the Fête Champêtre in New Spain" (2016).
} 
In this paper, I will revisit the Philadelphia shawl and offer some new ideas. Made in 1790, this shawl is a beautiful example of its type and period, featuring five bands of red angular designs created using the ikat, or jaspe dying method, repeated between four embroidered panels. The jaspe panels are bounded by very slender, but solid stripes of color. These repeated geometric forms provide a sense of rhythm and continuity in the rebozo's design.

The embroidered segments of the shawl depict a variety of scenes: boats float on the water, people dressed in an array of delicately rendered costumes reflecting the complex mix of races, as in casta paintings, interact and greet or dance with each other, tables set with food are interspersed among the motifs, and winding vegetal forms create a visual rhythm between the vignettes. These pastoral pleasures are all shown in relative perspective and scale according the embroiderer's ability, except for one enlarged anomaly: (Figure 2) a dragonfly depicted to halfhuman scale along the border of the garment.
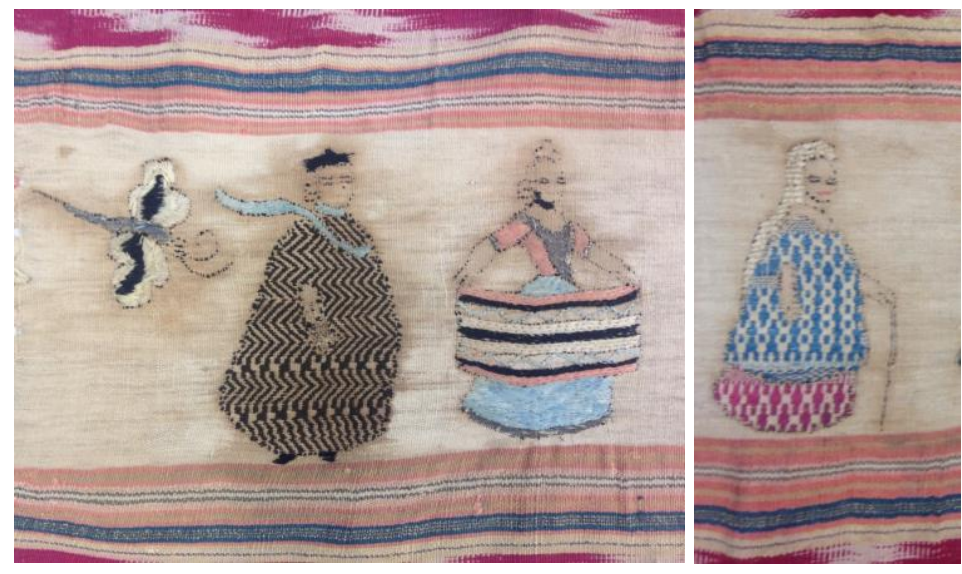

Figures 2 and 3. Details from Mexican Rebozo, late $18^{\text {th }}$ century, silk, embroidered with cotton, silk, and metallic thread, Philadelphia Museum of Art, Gift of Mes. George W. Childs Drexel, 1939, 1939-1-19.

Here, I argue that the shawl's weaver and/or embroiderer is depicted as a repeated indigenous figure in the vignettes (Figure 3) and I suggest that the dragonfly (see figure 2) serves as her signature. Through an investigation of the figures which I argue represent the maker, examples of signatures in embroidered samplers from the same region and period, and a discussion of dragonfly iconography in Mesoamerica, I demonstrate ways in which the indigenous figure depicted in this rebozo stands out and differentiates this shawl from other embroidered examples, adding an additional layer of meaning. In the Philadelphia rebozo, visual cues made to identify the maker, the importation, and the sale of rebozos within the shawl's own design creates a system of self-referentiality that brings the viewer's awareness not only to the scenes of the rebozo, but also to their creation, thereby facilitating a conceptual space for a signature (and agency) in the reading of the visual narrative.

The shawl contains several self-referential embroidered designs, that is, rebozos depicted within the design on the rebozo. Long shawls appear in the embroidered scenes a total of nine times: six as a worn garment, and three as an independent object, likely an accessory for sale (Figure 4). In one scene toward the top left of the design, the shawl makes its first appearance (adjacent to the dragonfly). Here, a woman holds a rebozo across her body, as if to let a couple view the 
handiwork evident in the shawl (Figure 5) and admire its artistry for potential purchase while they enjoy a refreshing beverage. Another vignette in the third embroidered band, slightly left of
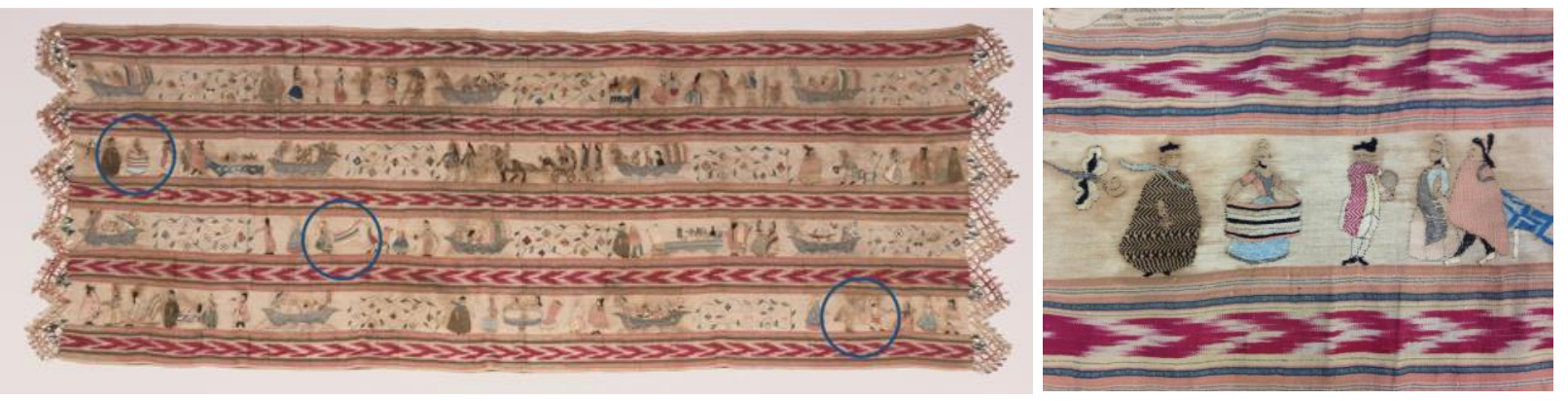

Figures 4 and 5. Details from Mexican Rebozo, late $18^{\text {th }}$ century, silk, embroidered with cotton, silk, and metallic thread, Philadelphia Museum of Art, Gift of Mes. George W. Childs Drexel, 1939, 1939-1-19.

center depicts a man and woman holding a shawl between them (Figure 6). The angle of the rebozo and the gentleman's body language lead the viewer to believe that they are seriously considering the shawl. Finally, in the lower right-hand corner, the rebozo is used as a prop in a dance (Figure 7).
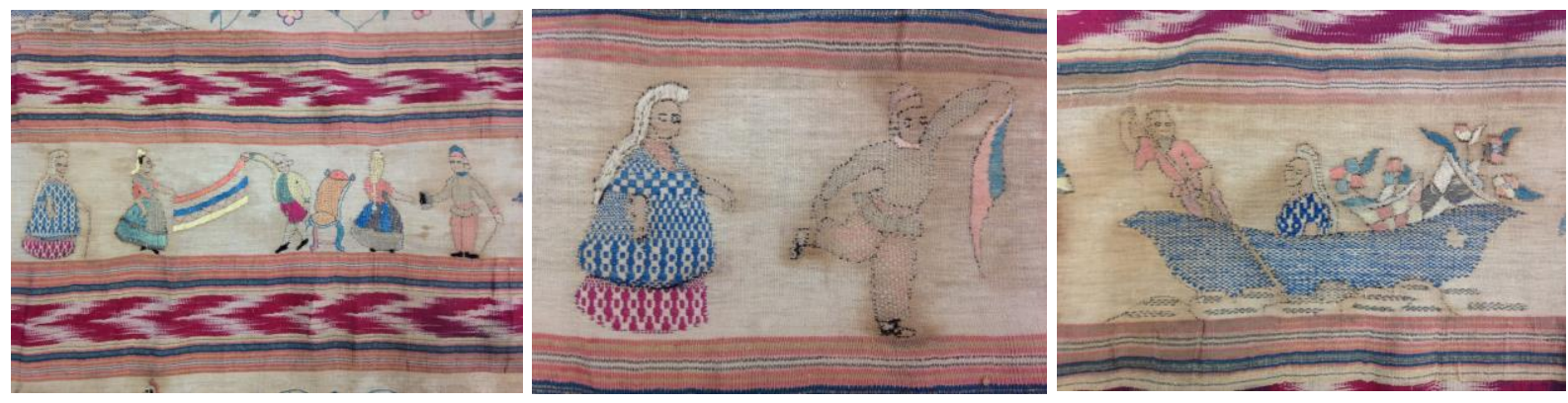

Figures 6, 7, and 8. Details from Mexican Rebozo, late $18^{\text {th }}$ century, silk, embroidered with cotton, silk, and metallic thread, Philadelphia Museum of Art, Gift of Mes. George W. Childs Drexel, 1939, 1939-1-19.

Twice in the display of the shawl the same woman accompanies the rebozo - an indigenous woman, clearly represented wearing a huipil (see figures 6 and 7). The huipil is a long and loose tunic that falls over an underskirt worn by indigenous groups in Mexico from ancient times to the present day. The dimensions and decorations of the patterned blue top and red skirt, and the headpiece in particular, correspond to depictions of similar costumes in casta paintings. If we search the shawl design for another representation of her, we find her in the top register at the center, riding in a boat filled with flowers, as if traveling to the location of the dia de campo to sell her wares (Figure 8). The same figure is evident with the shawl in the third embroidered row and in the last dancing scene (see figures 6 and 7). In the last two vignettes, she stands facing the shawl in observation with a cane, as a respected grandmotherly figure watching over her creation.

Hence, it becomes clear to the viewer that one of the stories the weaver/embroiderer is telling in these depictions is about the sale of the object itself. Although the story does not flow in a linear fashion, there are elements explaining a voyage, the display and inspection of the shawl, and its 
use in a dance. The indigenous figure stands out in the Philadelphia rebozo's design as the sole representative of her ethnicity and class and is visually linked repeatedly to the shawl, thereby causing the viewer to question not only who the scenes depicted, but who may have made them.

Given the association between the indigenous figure and the finely crafted shawl, I want to suggest that she is an example of an eighteenth-century pochteca (merchant). From the fifteenth through the seventeenth centuries the pochteca were members of the indigenous community charged with the responsibility of trading luxury goods that Mexica warriors and nobility used to indicate status and rank (Figure 9). Some examples happen to include textiles, such as cotton mantles, and clothing, as well as exotic feathers, semi-precious stones, ornaments of silver and gold, fur, cacao, and slaves. ${ }^{3}$ Further, it is possible that the indigenous figure in the Philadelphia shawl is not only the pochteca, but also the weaver or embroiderer of the shawl, based upon our understanding of pochtecas, which extends back to pre-contact times. In the sixteenth century, Fray Bernardino de Sahagún and his indigenous collaborators defined the pochteca in their various forms in Book 10 of the Florentine Codex. They classified the amanteca (feather artisan) as a subcategory within the trade of pochteca, or dealers. This connection between amanteca and pochteca is not only historical, but also religious, social, and economic. In Nahua communities, noble women became leaders of craft production, especially featherwork and textile work within the community. At the occasion of the Nahua girls' coming of age ceremonies, leaders gave speeches to their daughters, emphasizing their nobility and the importance of their work to the production of luxury goods within the community. ${ }^{4}$ Therefore, it is logical to suggest that the indigenous figure on the Philadelphia shawl is potentially both the craftswoman and the merchant of the scarves depicted within the embroidery, as well as the one at hand. This information also helps us to conclude that the ability to perform textile work was valued, and a point of pride - something the artisan/merchant might want to claim as an expression of agency through a signature.

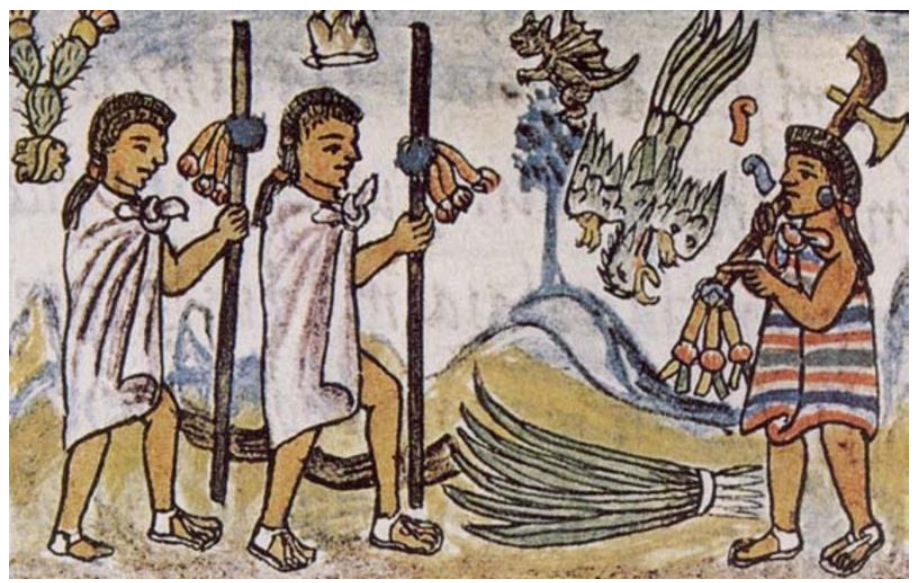

Figure 9. Pochteca, Florentine Codex, Bernardino, Arthur J. O. Anderson, and Charles E. Dibble. 1950. General history of the things of New Spain: Florentine codex. Image is in the Public Domain.

\footnotetext{
${ }^{3}$ Margarita Vargas (2019) “Angelina Martina: A Tlateloca Merchant or a Feather Artisan?” Paper presented at Beyond Biography, Gainesville, Florida, October 2019, https://ufdc.ufl.edu/IR00010635/00001, 4.

${ }^{4}$ Vargas, 4-6.
} 
Additionally, the indigenous figure in the Philadelphia shawl is shown using the visually descriptive signs of pochtecas in sources such as Sahagún's Florentine Codex and maps. Pochtecas are often depicted with footprints, indicative of a long journey. Our indigenous figure's journey is shown by boat, rather than by foot, but she has nevertheless taken, a journey. Pochtecas are shown with walking sticks (see figure 9). Our indigenous figure is shown with a walking stick (see figure 6 and figure 7, where the woman's hand is positioned for a walking stick, but none is embroidered). And Pochtecas appear with their wares, often on their backs. The indigenous figure in the Philadelphia rebozo is shown adjacent to, and watching over her wares, as explained above.

Now let us turn to the dragonfly (see figure 2). Despite several examples of appropriate spatial perspective throughout the embroidery on the shawl indicating the artist's ability, the dragonfly is grossly out of scale, measuring nearly three-quarters the height of the nearest human figure. The location of the dragonfly, while not dominant, is certainly not hidden. Placed at the beginning of the second row of embroidery, it accompanies the first appearance of the rebozo as an object, in lieu of the indigenous woman. Its presence is reminiscent of Aztec name glyphs, which appear slightly above figures in the scene, sometimes attached to the person named, but not always, as we saw in the Florentine Codex (see figure 9). Usually Aztec name glyphs depict a recognizable object that relates to the name. Maya name glyphs can be pictographic or logosyllabic, and they also can appear in the register above the human figure. It has been argued that some Maya stone monuments and stelae feature the signatures, or "name tags," of the artists.

In Maya cosmology, the dragonfly often represents IxChel, the patroness of weaving, divination, and midwifery. She is the goddess of fertility, pregnancy, and childbirth and her name can be translated as "Lady Rainbow." Thus, the symbol of an enlarged dragonfly, which stands as the patron of weavers, and refers to a "rainbow," is certainly an apt substitute for an image of the weaver-embroiderer of the Philadelphia rebozo, which is the representational function of a signature. $^{6}$

And so, this line of reasoning leads us to consider how - or if - this signature fits into other examples of embroidered signings. Who is doing embroidery in eighteenth-century Mexico, and have other name glyphs in lieu of signatures been identified? Although few examples of precontact embroidery exist due to Mexico's hot and humid climate, surviving fragments attest to the fact that decorative stitching was applied to clothing prior to the arrival of the Spaniards. ${ }^{7}$ After the conquest and the establishment of the Catholic Church in Mexico, nuns kept "whitework" available in their churches. In these textiles, the stitching is the same color as the background fabric, which was generally white linen. This term includes the technique of deshilado or "drawn threadwork," in which the artist chooses some threads to be pulled from the background fabric, while the rest are reinforced with additional stitching. One example from the Philadelphia Museum of Art depicts male figures on horseback alternating with lions across a long border, likely from the eighteenth century, and unsigned.

\footnotetext{
${ }^{5}$ Mary Miller and Karl Taube, An illustrated dictionary of the Gods and Symbols of Ancient Mexico and the Maya, (New York: Thames and Hudson, 1993) 100-101.

${ }^{6}$ Miller and Taube, 100-101.

${ }^{7}$ Victoria and Albert Museum, "Mexican Embroidery," accessed September 16, 2020, https://www.vam.ac.uk/articles/mexican-embroidery.
} 
Since the earliest days of the colonial period, girls of all ages and classes were taught to embroider, although it was predominantly men who were offered large commissions for clients such as the Catholic Church. In 1525, a school was established at the convent of San Francisco for the young girls in Texcoco, indigenous and Spanish alike, preparing to be beatas, or women who worked for the church, but were allowed to come and go within the community. ${ }^{8}$ Likewise, in the first half of the sixteenth century, women who were "not nuns and were called 'friends'," founded the Colegio de Niñas in Mexico City to teach the indigenous girls, a course in which embroidery naturally played a role. ${ }^{9}$ The intentions of these schools were to 1) Protect the young girls from the sensual rapacity of the men; 2) To instruct them in the Christian doctrine; 3 ) to teach the brightest to read and write; 4) To train them to help the missionaries in schools and hospitals. Let us add that teaching Spanish embroidery was also an act of assimilation. Thus, the colonial period provided a system of embroidery education for both Spanish and indigenous girls. Of course, time progressed, and by the eighteenth century for one socio-economic class of girls, embroidery became an art of accomplishment, or a skill that upper class young ladies used to show their sophistication and ability to create and maintain a beautiful home. They embroidered bedcovers, pillowcases, table cloths, furniture doilies, and samplers to demonstrate and practice their craft.

One such example can be seen in a sampler by Maria del Carmen Huerta from 1789 in Mexico. This is an example of needlework many of us are accustomed to seeing - one that incorporates different shapes, symbols, and letters in an effort to practice and record embroidery styles (Figure 10). The background is ivory plain weave with multicolored silk embroidery in cross, herringbone, basket, and satin stiches, also featuring cut and drawn-work in overcast bar stitch. ${ }^{10}$ The forms are drawn not only from Spanish embroidery traditions, such as mermaids and the coat of arms, topped by a crown and flanked by double-headed eagles, but are also derived from regional inspiration in architecture and motifs that appeared on indigenous clothing. An inscription in the center showcases a signature in a classic style: "(Empfso.) A Prender Maria del Carmen. Huerta, en el primero dechado (sample) ordinaro (plain) A. 23, D. Agto D L Ano 1789. (Ac bo E N Estejho mes Yanod.)" or "To teach Maria del Carmen Huerta, in her first plain sampler, $23^{\text {rd }}$ of August of the the year 1789."

The sampler is, of course, a very different type of embroidered textile than the rebozo at hand. The former is an example of an art of accomplishment featuring patterns made by a young woman of the upper class, while the rebozo was likely embroidered by an indigenous woman to sell as a souvenir that offers a commemorative narrative for a special occasion or trip. Although the institutional intentions in providing embroidery instruction were not originally to teach young ladies a skill they could monetize, this was, in part, the end result, at least for the "brightest" of the girls. When considering differences between signatures in Arabic script and image, as well as differences in class and privilege (both in the historical and the present contexts) we must also consider alternative literacies, keeping our own biases in check.

\footnotetext{
${ }^{8}$ Armella de Aspe, Virginia an Guillermo Tovar de Teresa, Bordados y Bordadores (Mexico City: Grupo Gutsa, 1992) 80-85.

${ }^{9}$ Armella de Aspe, 86.

${ }^{10}$ Philadelphia Museum of Art, "Sampler,” accessed September 16, 2020, https://www.philamuseum.org/collections/permanent/41104.html?mulR=831578243\%7C9.
} 


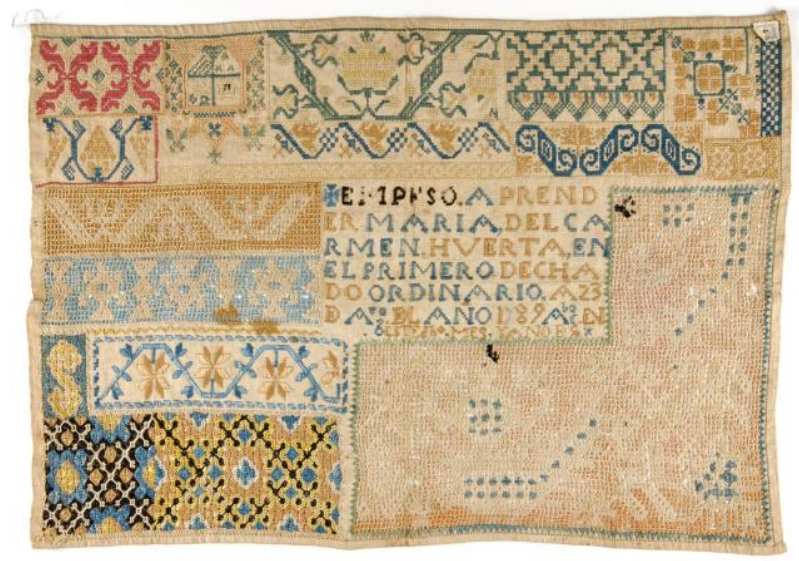

Figure 10. Maria Carmen del Huerta, Embroidery Sampler, Mexican, 1789, ivory linen plain weave with multi-colored silk embroidery, 26x19 3/4 inches. Purchased with the

Thomas Skelton Heritage Fund 1924, 1924-1-5.

Writing, in the Western mind, is often equated to graphically recorded speech. However, in Amerindian cultures, and certainly in Pre-Columbian America, art and writing are not easily categorized. Mechanisms of representation from an ethnohistoric perspective relied on visual thinking. ${ }^{11}$ As discussed above, both Mayan and Aztec "writing" forms incorporate images, and the Mayan form integrates sound with graphic representations. In Nahuatl, a language still spoken in Mexico today, the word tlacuiloliztli means both "to write" and "to paint;" a dichotomy made more intriguing with consideration of the crossovers between the terms amanteca and poshteca encountered earlier.

The Philadelphia rebozo presents a range of visual systems of graphic communication. The embroiderer created at least two narratives - one about a day spent dining, dancing, and listening to music in the countryside. The other is an autobiography. It is the portrait of the woman who makes, signs, and sells her own shawls as souvenirs to the elegant class of women who may be out for a dia de campo, and creating her own sampler at home, but who will treasure this indigenous maker's work for years to come. And so will we.

\footnotetext{
${ }^{11}$ Elizabeth Hill Boone, "Writing and Recording Knowledge," in Writing Without Words: Alternative Literacies in Mesoamerica and the Andes, Elizabeth Hill Boone and Walter D. Mignolo, eds. (Durham, NC: 1994) 3-6.
} 


\section{$\underline{\text { Bibliography }}$}

Armella de Aspe, Virginia and Guillermo Tovar de Teresa. Bordados y Bordadores. Mexico: Grupo Gutsa, 1992.

Armella de Aspe, Virginia, ed. Hilos del cielo: Las vestiduras litúrgicas de la Catedral Metropolitana de México. Mexico City: Instituto Nacional de Antropología e Historia, Oficina de Catálogo, 2007.

Castello Yturbide, Teresa. El rebozo. Mexico: Electrocomp, 1979.

Castelló Iturbide, Teresa and Margarita de Orellana. "El rebozo," in Artes de México 90. México D.F.: Artes de México, 2008.

Laughlin, Eleanor A., "The Intercontinental Reflections of an Eighteenth-Century Mexican Rebozo" (2016). Textile Society of America Symposium Proceedings. http://digitalcommons.unl.edu/tsaconf/1022

Miller, Mary and Karl Taube. An illustrated dictionary of the Gods and Symbols of Ancient Mexico and the Maya. New York: Thames and Hudson, 1993.

Philadelphia Museum of Art, "Sampler," accessed September 16, 2019, https://www.philamuseum.org/collections/permanent/41104.html?mulR=831578243\%7C 9.

Phipps, Elena. "Shawl (Rebozo)." In Interwoven Globe: The Worldwide Textile Trade 15001800, edited by Amelia Peck. New York: Metropolitan Museum of Art, 2013.

Sayer, Chloe. Costumes of Mexico. Austin: University of Texas Press: 1985.

—. Textiles from Mexico. Seattle: University of Washington Press, 2002.

—. Mexico: Clothing and Culture. Ontario: Royal Ontario Museum of Art, 2015.

Thomas, Mary. Mary Thomas's Dictionary of Embroidered Stitches. London: Hodder and Stoughton, 1989.

Vargas, Margarita. (2019) “Angelina Martina: A Tlateloca Merchant or a Feather Artisan?" Paper presented at Beyond Biography, Gainesville, Florida, October 2019, https://ufdc.ufl.edu/IR00010635/00001

Velázquez, Gustavo G. El rebozo en el estado de México. México: Instituto Mexiquence de Cultura, 2002.

Victoria and Albert Museum, "Mexican Embroidery," accessed September 16, 2020, https://www.vam.ac.uk/articles/mexican-embroidery 